\title{
Estudio de la fisuración de la fábrica de ladrillo con un modelo de fisura cohesiva
}

\author{
Study of the brickwork masonry cracking with a cohesive \\ fracture model
}

\author{
E. Reyes ${ }^{(*)}$, M. J. Casati(*), J. C. Gálvez ${ }^{(*)}$
}

Recepción/Received: 16-II-10

Aceptación/Accepted: 7-VII-10

Publicado online/Online publishing: 16-XII-10

RESUMEN

Este artículo presenta un modelo de cálculo que permite simular el comportamiento en rotura de la fábrica de ladrillo bajo solicitaciones de tracción y cortante. El modelo extiende el modelo cohesivo formulado por los autores para hormigón, considerando la anisotropía del material. El procedimiento de cálculo consta de dos fases: 1) obtención de la trayectoria de grieta mediante un cálculo elástico lineal; 2) incorporación del modelo cohesivo en la misma mediante elementos de intercara. El modelo se ha implementado en un programa de elementos finitos comercial con una subrutina de usuario y se ha contrastado con los resultados experimentales de los ensayos a escala. Las propiedades mecánicas de la fábrica, en especial las de fractura, se miden con ensayos de caracterización en dos direcciones. Éstas se incorporan al modelo de cálculo para simular los ensayos de fractura en modo mixto, prediciendo los resultados adecuadamente para distintas orientaciones de los tendeles.

Palabras clave: ladrillo, fisuración, resistencia a tracción, resistencia a cortante, simulación numérica.

\begin{abstract}
SUMMARY
This paper presents a numerical procedure to simulate the cracking process of the brickwork masonry under tensile/shear loading. The model is an extension of the cohesive model developed by the authors for concrete, and takes into account the anisotropy of the material. The numerical procedure includes two steps: 1) calculation of the crack path with a linear elastic fracture model; 2) after the crack path is obtained, an interface finite element (using the cohesive fracture model) is incorporated into the trajectory. Such a model is then implemented into a commercial code by means of a user subroutine, consequently being contrasted with experimental results. Fracture properties of masonry are independently measured for two directions on the composed masonry, and then input in the numerical model. This numerical procedure accurately predicts the experimental mixed mode fracture records for different orientations of the brick layers on masonry panels.
\end{abstract}

Keywords: brick, fracture, tensile strength, shear strength, numerical modeling.

(*) Universidad Politécnica de Madrid (Madrid, España).

Persona de contacto/Corresponding author: jaime.galvez@upm.es 


\section{INTRODUCCIÓN}

En un artículo previo (1) los autores han puesto de manifiesto que la fábrica de ladrillo, empleada habitualmente para la construcción de elementos de cierre y divisorios en edificación, presenta con frecuencia problemas de agrietamiento como consecuencia de su escasa capacidad para acompañar a los elementos estructurales, forjados y vigas, en sus movimientos durante la vida en servicio (2). Se trata de un problema de fractura en el que el muro de fábrica se agrieta bajo una solicitación en modo mixto (tracción y cortante) con carga cuasiestática.

Hasta ahora el estudio de los mecanismos de fallo de la fábrica se ha centrado fundamentalmente en las solicitaciones de compresión y compresión/cortante (3-7), habiéndose estudiado poco el fallo bajo solicitaciones de tracción y cortante (8-13). El trabajo (1) proporciona resultados experimentales de fractura en modo mixto de probetas de fábrica de dimensiones reducidas. El presente artículo presenta un modelo de cálculo que permite reproducir el comportamiento de fractura de la fábrica, y se verifica con los resultados experimentales (1).

La fábrica de ladrillo se puede considerar como un material compuesto, formado por la disposición ordenada, de acuerdo con el tipo de aparejo, de ladrillos unidos por un mortero. El resultado es un material altamente heterogéneo y anisótropo, en el que las juntas de mortero representan usualmente planos de debilidad en la estructura.

Dependiendo de la escala a la que se estudie, la modelización de la fábrica puede abordarse con diferentes niveles de aproximación, desde una representación detallada de los ladrillos, el mortero y las juntas existentes entre ambos (3, 14), hasta un análisis global de la estructura, considerándola como un continuo con comportamiento isótropo o bien anisótropo (15-17). El grado de refinamiento debe estar directamente relacionado con el tipo de problema a analizar. Una micromodelización del problema $(10,17,18)$ es útil para el análisis detallado de los fallos de la fábrica de elementos estructurales de pequeño tamaño. En cambio, el análisis del fallo estructural de estructuras de fábrica de gran tamaño o geométricamente complejas utilizando este tipo de modelos es prácticamente inabordable. Además, algunos de los parámetros del material necesarios para el cálculo son muy difíciles de medir en estructuras reales, especialmente en el caso de estructuras antiguas. Algunos autores han utilizado para estos casos técnicas de homogeneización (19-20) con buenos resultados. Estas técnicas son muy útiles en el análisis numérico de problemas mecánicos de estructuras de fábrica, reduciendo el coste computacional, sin embargo presentan dificultades prácticas aún sin resolver. La modelización a nivel mesoscópico representa una forma complementaria de aproximación a la fractura de

\section{INTRODUCTION}

Nowadays, brickwork masonry is profusely used for façades and internal walls in buildings with a concrete structure (1). A frequent problem of brickwork masonry structural elements and walls is cracking, associated with differential settlements and/or excessive deflections of slabs throughout the service life of the structure (2). Cracking of masonry is caused by the fragility and low capacity of the masonry, when accompanying structural elements such as floors, beams or foundations, in their movements. This problem is usually one of fracturing, where the wall is cracked under mixed mode fracture under quasi-static loading.

Until now, the study of brick masonry failure has been focussed on compression and compression/shear failure mechanisms (3-7), and practically nothing (based on the fracture mechanics approach), to tensile/shear failure (813). Reference (1) supplies experimental results of mixed mode fracture tests with brickwork scaled specimens. This work presents a numerical procedure for mixed mode fracture of masonry, and it is checked with these experimental results (1).

Brickwork masonry is a composite material formed by the orderly disposition, according to the type of pattern, of bricks united by a mortar. The result is a material highly inhomogeneous and anisotropic, where the mortar joints beforehand usually represent weakness planes in the structure.

Depending on the scale, the modelling of the masonry can be performed with different levels of abstraction, from a detailed representation of bricks, mortar and joints $(3,14)$ to a global analysis as an isotropic or anisotropic continuum (15-17). The grade of refinement is directly related with the problem being analysed. $A$ micro-modelling approach $(10,17,18)$ is useful for detailed analysis of the masonry failures on a small size structural element. However, the failure analysis of large and geometrically complex structures using these models is usually unfeasible. Some of the parameters of the material needed for computation being quite difficult to measure in real (especially ancient) buildings. Homogenisation techniques (19-20), are very useful in the numerical analysis of these problems and reduce the computational cost, though certain practical difficulties do remain. A meso-modelling approach represents a complementary way to model the masonry fracture of 
fábrica $(8,11-13,21,22)$ de grandes estructuras, obviando las dificultades prácticas de los micromodelos.

Este artículo presenta un procedimiento de cálculo a escala mesoscópica para el análisis de la fractura en modo mixto de la fábrica de ladrillo basado en el modelo de fisura cohesiva. El modelo no distingue entre los ladrillos, mortero y juntas, promediando el comportamiento del material compuesto a través de la formulación de un material continuo equivalente. Se asume que el material es homogéneo y anisótropo. El modelo ha sido utilizado con éxito al estudiar la fractura en modo mixto de morteros y hormigones $(23,24)$, que son considerados como materiales homogéneos e isótropos a escala mesoscópica. En este trabajo el modelo se extiende a materiales anisótropos. Esta aproximación es adecuada para estudiar el fallo de la fábrica cuando se genera una o varias fisuras discretas en elementos estructurales de tamaño suficientemente grande. El modelo requiere medir las propiedades de fractura de la fábrica en, al menos, dos direcciones principales del material. El modelo de fisura cohesiva anisótropa es capaz de predecir el comportamiento de la fábrica en su conjunto, sin necesidad de hacer uso de ningún tipo de procedimiento de ajuste o de refinado. La verificación del modelo se ha realizado con los resultados de los ensayos de fractura sobre probeta compacta con doble entalla (PCDE) presentados en (1).

Este trabajo no se plantea como un estudio a escala de la fractura de la fábrica de ladrillo real, para lo que sería necesario contar con resultados de ensayos de fractura de fábrica a escala natural (1:1), sino que pretende mostrar la viabilidad e interés de aplicar modelos cohesivos de fractura al estudio del agrietamiento de la fábrica de ladrillo. Lógicamente, aún es necesario desarrollar un extenso trabajo antes de aplicar estos modelos con fiabilidad a las complejas estructuras de fábrica, especialmente si éstas son antiguas.

En la siguiente sección se describe el modelo numérico. La sección 3 resume el programa experimental empleado. Las predicciones numéricas de los ensayos de fractura en modo mixto se presentan y discuten en la sección 4. Finalmente, las conclusiones obtenidas a partir del modelo y de los ensayos se presentan en la sección 5.

\section{MODELO COHESIVO DE FRACTURA}

Como se ha indicado, en este trabajo se ha elegido un modelo a escala mesoscópica. Esta aproximación no hace distinción entre los distintos componentes de la fábrica (ladrillos, mortero y juntas), promediando el efecto del material compuesto a través de la formulación de un material continuo equivalente. Este material es homogéneo, anisótropo y presenta un comportamiento large structures $(8,11-13,21,22)$, avoiding practical difficulties of the micro-modelling.

This paper presents a meso-mechanical procedure for the analysis of mixed mode fracture of brick masonry based on the cohesive crack approach. The model does not make any distinction between masonry units (bricks), mortar and joints, averaging the effect of the composite material through the formulation of a fictitious continuous material. The material is assumed to be homogeneous and anisotropic. The model has been successful for mixed mode fracture of concrete and mortar $(23,24)$, which are considered homogenous and isotropic materials at meso-level approach. In this work the model is extended to anisotropic materials, with the approach being promising when failure is governed by the development of a single macro-crack in large structural brick masonry elements. With this model as a framework, fracture properties of the entire masonry are independently determined for, at least, two main directions of masonry by specific tests performed on this material, then being input to numerical simulation, where masonry is treated as the only material. The result is an anisotropic cohesive fracture model, which can predict the behaviour the whole masonry without resort to any kind of fitting or tuning procedure. The model is checked with experimental results of (1).

This work is not intended to be a small-scale testing nor modelling of real masonry walls. With this paper, the authors seek to emphasise that with this new approach, based on the cohesive crack modelling applied to masonry, it is possible to analyse the mixed mode fracture behaviour of this complex material. It is acknowledged that further work must be carried out to extend this modelling to full-scale masonry structures.

Whereas the following section examines the numerical modelling, section 3 summarized the experimental programme. Numerical predictions of the mixed mode fracture tests are then presented and discussed in section 4. Finally, the conclusions obtained from the model and the experiments are presented in section 5.

\section{COHESIVE FRACTURE MODEL}

As mentioned above, the meso-scale approach is adopted in this work. Such an approach does not make any distinction between masonry bricks, mortar and joints, averaging the effect of the composite material through the formulation of a fictitious continuous material. This material is homogeneous, anisotropic and shows cohesive behaviour under tensile cracking. The 
cohesivo bajo fisuración por tracción y cortante. El modelo parece adecuado cuando el fallo está gobernado por el desarrollo de una única fisura, o un número discreto de ellas, en un elemento estructural de tamaño suficientemente grande, como es el caso de fisuración en muros de ladrillos provocada por asientos diferenciales.

El procedimiento de cálculo propuesto consta de dos etapas: 1) obtención de la trayectoria de grieta mediante un cálculo elástico lineal y, 2) incorporación del modelo cohesivo anisótropo en la trayectoria de grieta con elementos de intercara. Estas dos etapas son fases del cálculo independientes.

El modelo de fisura cohesiva (25), propuesto inicialmente por Hillerborg para hormigón y morteros, se ha empleado satisfactoriamente en fábrica de ladrillo (10-12).

El modelo de fisura cohesiva introduce la función de ablandamiento para simular la fisuración y deterioro del material en la zona en proceso de fractura. El comportamiento de esta zona se representa mediante una fisura cohesiva, capaz de transferir tensiones entre las caras de la grieta. Para la configuración más simple, aquella en la que la fisura se abre en modo I, la tensión cohesiva en un determinado punto es normal a las caras de la fisura y está unívocamente fijada por la curva de ablandamiento como una función de la abertura de fisura $\omega$ en ese punto, $\sigma=\mathrm{f}(\omega)$, como se muestra en la Figura 1. La curva de ablandamiento relaciona la tensión transferida entre las caras de la fisura en un determinado punto de la misma y la abertura de fisura en ese mismo punto, y por hipótesis se considera una propiedad del material, independiente de la geometría y del tamaño. approach is suitable when the failure is governed by the development of a single macro-crack in a large masonry structural element.

The numerical modelling of the mixed mode (I/II) fracture process of masonry is based on the incorporation of the cohesive crack model into a finite element code. The two main stages of the process are the calculation of the crack path and the incorporation of the cohesive interface crack model into the crack path; these stages are two different computational steps.

The cohesive crack model, proposed by Hillerborg (25) for concrete and mortar, has been successful in the analysis of the fracture of masonry (10-12).

The cohesive crack model introduces the softening function to simulate the cracking and deterioration of the material in the fracture process zone. This zone is modeled by means of a cohesive crack, which can transfer stress, the cohesive stress, from one face to the other. For the simplest configuration, where a crack opens loaded in mode $I$, the cohesive stress at a given point is normal to the crack faces and is uniquely given by the softening curve as a function of the crack opening at this point $\sigma=f(\omega)$, as shown in Figure 1. The softening function relates the stress transferred between the crack faces to the crack opening at this point, and it is considered by hypothesis to be a material property, independent of geometry and size.

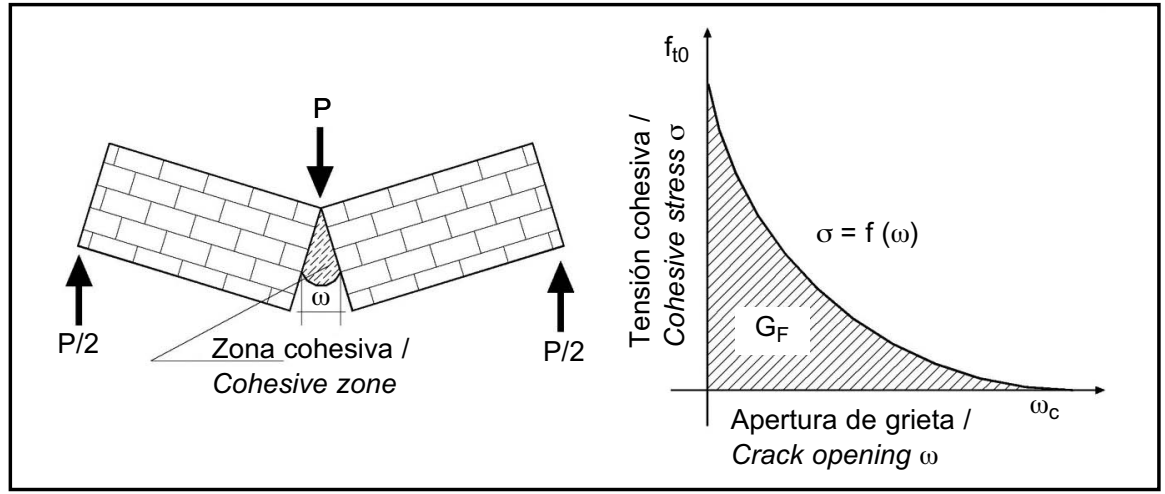

Figura 1. Fisura cohesiva y curva de ablandamiento para fractura en modo I de materiales cuasi-frágiles. Figure 1. Cohesive crack and softening function for mode I fracture of cohesive materials.

Las propiedades más importantes de la curva de ablandamiento son: la resistencia a tracción, $f_{\mathrm{t} 0}$, y la energía de fractura, $G_{F}$. La resistencia a tracción es la tensión a la cual se crea la fisura y empieza a abrirse $\left(f(0)=f_{\text {to }}\right)$.
Two properties of the softening curve are most important: the tensile strength, $f_{t 0}$, and the cohesive fracture energy, $G_{F}$. The tensile strength is the stress at which the crack it is created and starts to open $\left(f(0)=f_{t 0}\right)$. The cohesive 
La energía de fractura, $G_{F}$, también denominada energía específica de fractura, es la energía externa necesaria para crear una unidad de superficie de fisura cohesiva completamente abierta, y coincide con el área existente bajo la curva de ablandamiento.

El modelo de fisura cohesivo propuesto para fractura en modo I (25) se ha extendido con éxito a la fractura en modo mixto (I/II) de hormigón $(23,24,26)$. En este artículo el modelo se amplía a materiales anisótropos, como la fábrica de ladrillo. El modelo incluye la dependencia de la energía específica de fractura, la resistencia a tracción y el módulo de elasticidad respecto de la dirección del material (orientación de los tendeles).

\subsection{Trayectoria de la fisura}

La experiencia de trabajos previos para el cálculo de las trayectorias de grietas en materiales frágiles (27) y cuasi-fragiles $(23,24,28)$ permite adoptar el Criterio de Máxima Tensión Circunferencial, según el cual la fisura crece perpendicularmente a la dirección de mayor tensión de tracción. El cálculo numérico de las tensiones y, por tanto, de la trayectoria de grieta se ha realizado con el código de elementos finitos FRANC2D (29).

\subsection{Superficie de rotura para fractura en modo mixto}

El modelo de fisura cohesiva para modo I (25) reproduce el comportamiento de la zona en proceso de fractura con la curva de ablandamiento, que relaciona la tensión normal, $\sigma$, transferida a través de las caras de la grieta con su apertura, $\omega$, tal y como muestra la Figura 1 . En el caso de la fractura en modo mixto (tracción/cortante), además de la apertura de grieta, hay un desplazamiento tangencial relativo entre las caras de la grieta. Se define el vector $\mathbf{u}$, como vector de desplazamiento relativo entre las caras de la fisura cohesiva del siguiente modo [1]. fracture energy, $G_{F}$, also called specific fracture energy, is the external energy required to create and fully break a unit surface area of a cohesive crack one which coincides with the area under the softening function.

The authors have successfully expanded on this model, originally developed for mode I fracture (25), to mixed mode fracture (I/II) of concrete $(23,24,26)$. In this paper the cohesive model for mixed mode fracture is extended to an anisotropic material, such as brickwork masonry. The model includes the dependence to the specific fracture energy, tensile strength and elastic modulus on the direction of the material (orientation of the bed joints).

\subsection{Prediction of the crack path}

Linear Elastic Fracture Mechanics (LEFM) has proved its worth in predicting the crack path for brittle materials (27) and even for quasi brittle materials (23, 24, 28). In this work, numerical computations use the Maximum Circumferential Stress Criterion, which postulates that the crack grows perpendicularly to the greatest tension. The LEFM finite element code FRANC2D (29) was used to calculate the crack paths.

\subsection{Cracking surface for mixed mode fracture}

The cohesive crack model for mode I (25) reproduces this behaviour through the softening curve that relates the normal stress, $\sigma$, transferred across the cohesive crack faces, as shown in Figure 1. In the case of mixed mode (tensile and shear stresses) fracture, relative displacement, $\boldsymbol{u}$, between the upper and lower faces of the cohesive crack is a vector, with normal and shear components, denoted as $u_{n}$ and $u_{t}$ respectively, as shown in [1].

$$
\mathbf{u}=u_{n} \vec{n}+u_{t} \vec{t}
$$

donde $\vec{n}$ y $\vec{t}$ son los vectores unitarios normal y tangencial, respectivamente, a una de las caras de la fisura, elegida como cara de referencia (cara inferior).

La tensión transferida entre las caras de la fisura tiene también naturaleza vectorial, y está caracterizada por el vector tracción $\mathbf{t}$, actuando sobre la cara de referencia de la fisura, con las componentes normal y tangencial notadas como $\sigma$ y $\tau$, i.e. [1]. where $\vec{n}$ and $\vec{t}$ are the unit vectors respectively normal and tangential to the lower crack face.

Likewise, the stress transferred between the faces of the crack is also vectorial, and is characterised by the traction vector $\boldsymbol{t}$ acting on the lower face of the crack; with normal and tangential components denoted as $\sigma$ and $\tau$, i.e. [2].

$$
\mathbf{t}=\sigma \vec{n}+\tau \vec{t}
$$


De forma análoga a la curva de ablandamiento en modo I, es necesario establecer una relación entre el vector tracción $\mathbf{t}$ y el vector de desplazamiento relativo de la fisura $\mathbf{u}$. En este trabajo hemos adoptado una formulación elastoplástica en la que el desplazamiento entre los labios de la fisura se separa en sus partes elástica y plástica [3].
At this point the formulation of the cohesive crack model in mixed mode requires establishing the relationship between the traction vector $\boldsymbol{t}$ and the crack displacement vector $\boldsymbol{u}$. In this work we adopt an elastoplastic formulation in which the crack displacement is split into its elastic and inelastic parts [3].

$$
\mathbf{u}=\mathbf{u}^{e}+\mathbf{u}^{i}
$$

De tal forma que el vector tracción viene dado por [4].

so that the traction vector is given by [4].

$$
\mathbf{t}=\mathbf{K}_{e} \mathbf{u}_{\mathrm{e}}
$$

donde $\mathbf{K}_{e}$ es un tensor elástico de segundo orden. Se asume que las componentes normal y tangencial están desacopladas. Por lo tanto, la matriz de componentes de $\mathbf{K}_{e}$ en la base $\{\vec{n}, \vec{t}\}$ es diagonal. Además, la rigidez normal y tangencial son iguales, de forma que la matriz de componentes es [5]. where $\mathbf{K}_{\mathbf{e}}$ is a second order elastic stiffness tensor. In the present work we assume that the shear and normal components are uncoupled. Therefore, the matrix of components of $\mathbf{K}_{\mathbf{e}}$ in the basis $\{\overrightarrow{\mathrm{n}}, \overrightarrow{\mathrm{t}}\}$ is diagonal. We further assume that the normal and shear stiffness are identical, so that the matrix of components is actually [5].

$$
\mathbf{K}_{e}=K^{e}\left[\begin{array}{ll}
1 & 0 \\
0 & 1
\end{array}\right]
$$

Idealmente, la rigidez inicial de la fisura cohesiva debería ser infinita para reproducir el comportamiento de rigidez-ablandamiento de la fisura cohesiva. Sin embargo, a efectos de los cálculos numéricos, se han adoptado valores muy grandes pero finitos del parámetro $K^{e}$ para evitar problemas de convergencia. En este trabajo se han adoptado valores de $K^{e}$ tales que se alcanza la tensión y cohesión máximas con desplazamientos de 0,001 $\omega_{C \prime}$ donde $\omega_{c}$ es la abertura de fisura que agota la curva de ablandamiento (véase la Figura 1).

Para el comportamiento inelástico, se asume que la abertura de fisura inelástica progresa cuando se alcanza la llamada superficie de rotura, $\mathbf{F}(\mathbf{t})=0$, que juega un papel similar a la superficie de plastificación en la plasticidad clásica. Se adopta la siguiente expresión hiperbólica $(23,30)[6]$.
Ideally, the initial stiffness of the cohesive crack would have to be infinite to reproduce the rigid-softening behaviour of a cohesive crack. For numerical computations, however, some large but finite value has to be adopted for $K^{e}$. In this work we adopted values of $K^{e}$ so that the normal or shear crack displacement at peak were around $0.001 \omega_{c}$ where $\omega_{c}$ is the crack displacement for which full softening has occurred (see Figure 1).

For the inelastic behaviour, it is assumed that the inelastic crack opening can progress when the so called cracking surface $\mathbf{F}(\mathbf{t})=0$ is reached, similar to the yield surface in classical plasticity. For an isotropic material the following hyperbolic expression has been assumed by the authors $(23,30)[6]$.

$$
\mathbf{F}(\mathbf{t})=\tau^{2}-2 \mathrm{ctan} \phi_{f}\left(f_{t}-\sigma\right)-\tan ^{2} \phi_{f}\left(\sigma^{2}-f_{t}^{2}\right)
$$

donde $\phi_{f}, c$ y $f_{t}$ son los valores instantáneos del ángulo de fricción, la cohesión y la resistencia a tracción, respectivamente. Estos valores dependen únicamente de la historia de carga. En el caso de un material anisótropo dependen, además, de la dirección que la fisura forme con las direcciones principales del material.

El ángulo formado entre la dirección de mayor tensión de tracción y los tendeles se nota como $\theta$, de modo que la ecuación 6 queda como sigue [7]. where $\phi_{f}, c$ and $f_{t}$ are the instantaneous values of the friction angle, cohesion and tensile strength, respectively. Such values only depend on loading history. In the case of an anisotropic material, they also depend on the direction that the crack forms with the main directions of the material.

In this work we denote the angle between the greatest tensile stress and the bed joints as $\theta$. After introducing this notation, the Equation 6 is expressed as follows [7].

$$
\mathbf{F}(\mathbf{t})=\tau^{2}-2 \mathrm{c}(\theta) \tan \phi_{f}\left(f_{t}(\theta)-\sigma\right)-\tan ^{2} \phi_{f}\left(\sigma^{2}-f_{t}(\theta)^{2}\right)
$$


donde $\mathrm{c}(\theta)$ y $f_{t}(\theta)$ son los valores instantáneos de la cohesión y la resistencia a tracción para el ángulo $\theta$. Estos parámetros dependen de la historia de carga a través del desplazamiento inelástico efectivo uieff, definido como [8], [9]. where $c(\theta)$ and $f_{t}(\theta)$ are the instantaneous values of the cohesion and tensile strength for $\theta$ angle. These parameters are assumed to depend on the loading history only through the effective inelastic crack displacement uieff, defined by the conditions [8], [9].

$$
\begin{gathered}
\dot{u}^{\text {ieff }}=\left|\dot{\mathbf{u}}_{\mathrm{i}}\right|=\sqrt{\dot{u}_{\text {in }}^{2}+\dot{u}_{i t}^{2}} \\
u^{\text {ieff }}=\int \dot{u}^{\text {ieff }} \mathrm{d} t
\end{gathered}
$$

En este trabajo se asume que, para un material dado, el ángulo de fricción $\phi_{f}$ es constante, mientras que la resistencia a tracción instantánea $f_{t}(\theta)$ y la cohesión $\mathrm{c}(\theta)$ dependen de uieff, según una función bilineal, como se muestra en la Figura 2. En el caso de un material anisótropo, los valores de $f_{\text {to }}$ y $f c_{0}$ dependen del ángulo $\theta$. Por simplicidad se asume una variación lineal de $f_{t 0}$ y $c_{0}$ con el ángulo $\theta$, como se muestra en la Figura 3.
In this work we assume that, for a given material, the friction angle $\phi_{f}$ is constant, while the instantaneous tensile strength $f_{t}(\theta)$ and cohesion $c(\theta)$ depend on uieff bilinearly as depicted in Figure 2. In the case of an anisotropic material the values of $f_{\text {to }}$ and $f_{c_{0}}$ depend on the $\theta$ angle. For the sake of simplicity we assume a linear variation of $f_{\text {to }}$ and $c_{0}$ in relation to $\theta$ angle, as is showed in Figure 3.

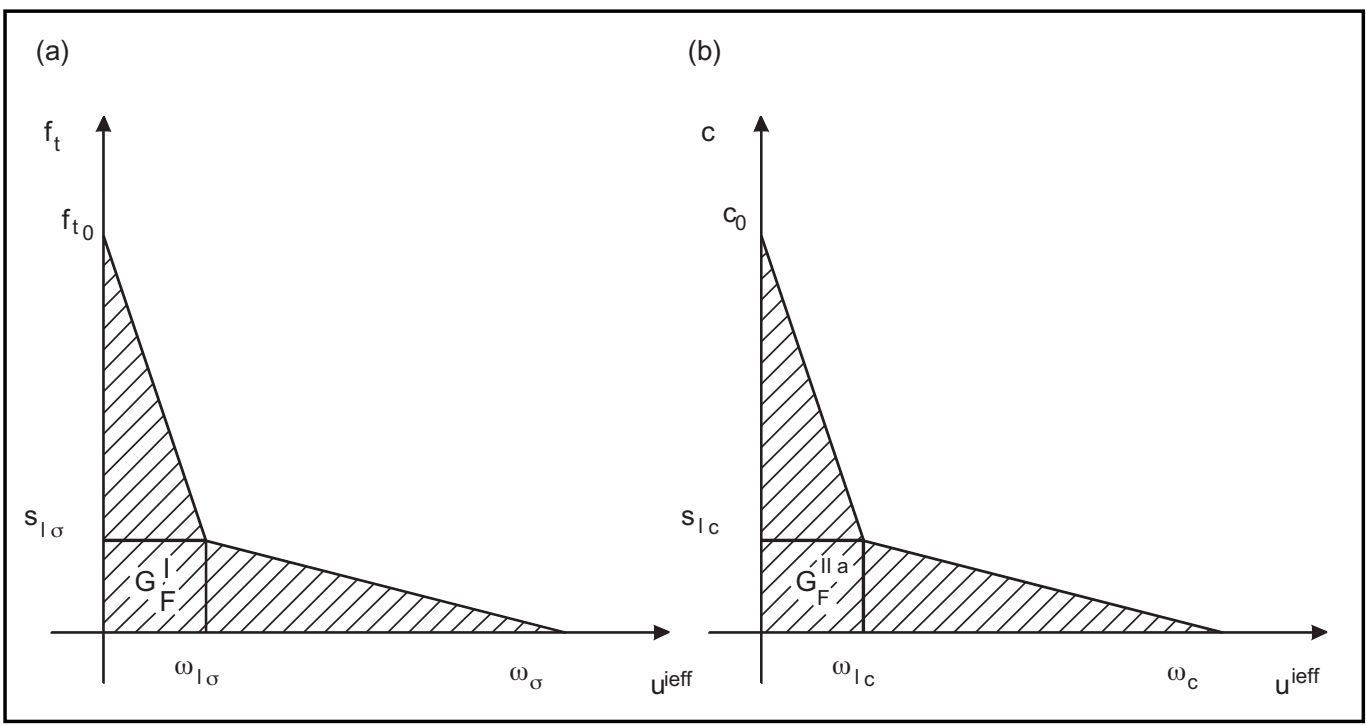

Figura 2. Curvas de ablandamiento: a) resistencia a tracción, $\left.\mathrm{f}_{\mathrm{t}}(\theta), \mathrm{b}\right)$ cohesión, $\mathrm{c}(\theta)$. Figure 2. Softening curves for brick masonry: a) tensile strength, $\left.f_{t}(\theta), b\right)$ cohesion, $c(\theta)$.

El área encerrada bajo la curva de ablandamiento de es la energía específica de fractura $G_{F}^{I}$ para modo I (llamada normalmente energía de fractura). Análogamente, el área delimitada bajo la curva de ablandamiento de la cohesión tiene dimensiones de energía por unidad de área y fue denominada energía específica de fractura para modo IIa, $G_{F}^{I I a}(23)$. El parámetro $G_{F}^{I I a}$ no es directamente medible, ya que no es posible la realización de un ensayo experimental en el que el trabajo de fractura sea en modo II puro. Habitualmente el valor de $G_{F}^{I I a}$ se estima con la relación $G_{F}^{I I a} / G_{F}^{I}(23)$.
The area enclosed between the softening curve and the axes is the specific fracture energy $G_{F}^{I}$ for mode $I$ (usually called fracture energy). Likewise, the area defined by the softening curve for the cohesion and the axes also has dimensions of energy per unit area and was called the mode IIa specific fracture energy $G_{F}^{I I a}$ (23). This parameter, $G_{F}^{I I a}$, is not directly measurable as no test can be devised in which the work of fracture is uniquely related to $G_{F}^{I I a}$. Usually, the $G_{F}^{\text {IIa }}$ is adopted by estimation of the ratio $G_{F}^{I I a} / G_{F}^{I}(23)$. 


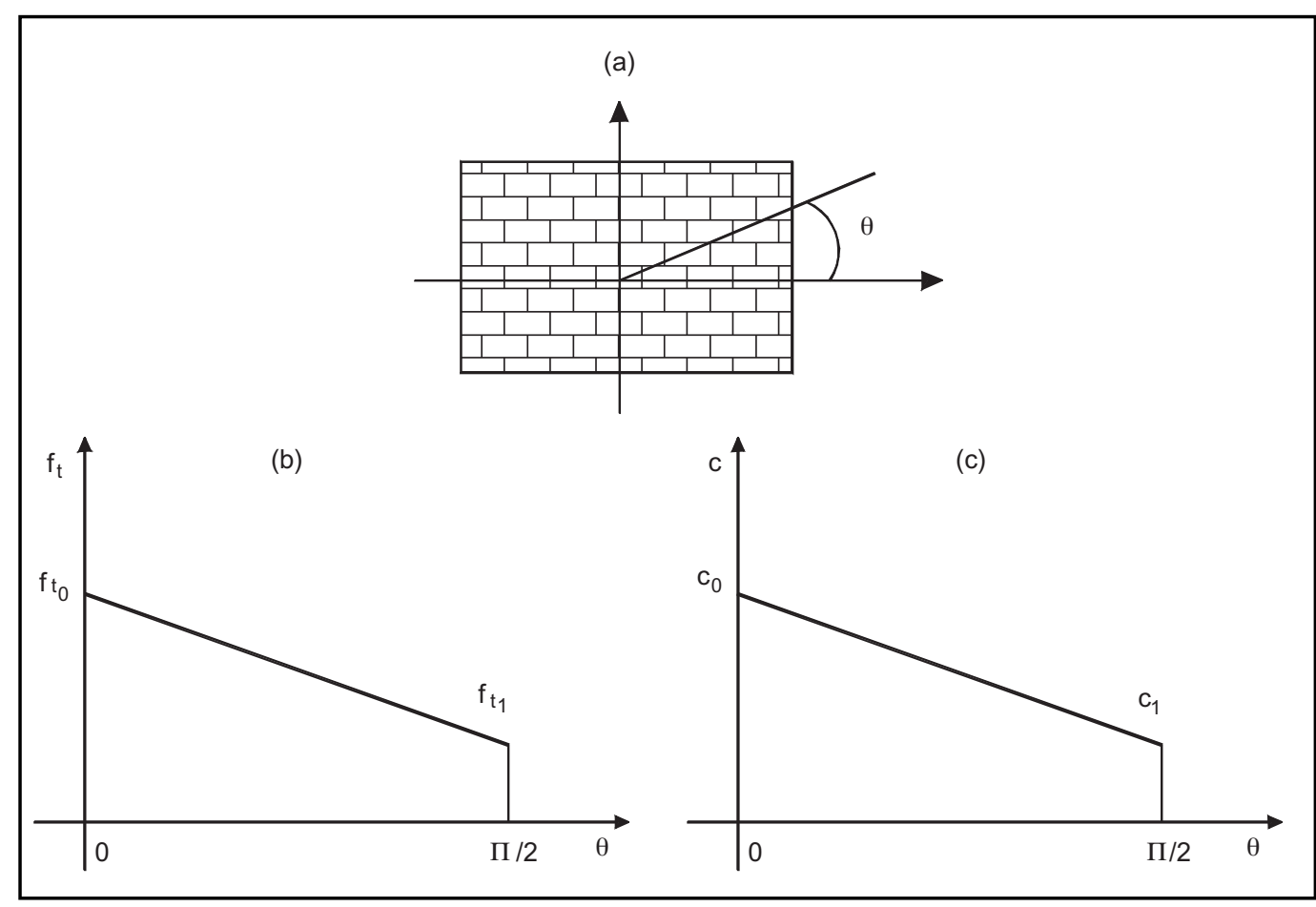

Figura 3. Ley lineal de variación: a) ángulo que forma la dirección de propagación de la fisura con la orientación de los tendeles, $\theta, \mathrm{b}$ ) resistencia a tracción máxima para el ángulo $\left.\theta, \mathrm{f}_{\mathrm{t}}(\theta), \mathrm{c}\right)$ cohesión máxima para el ángulo $\theta, \mathrm{c}(\theta)$. Figure 3. Linear variation: a) angle between greatest tensile stress and bed joints, $\theta, b)$ maximum tensile strength for $\theta$ angle, $f_{t}(\theta)$, c) maximum cohesion for $\theta$ angle, $c(\theta)$.

La curva bilineal de ablandamiento de la resistencia a tracción de la fábrica (véase Figura $2 a$ ) se puede obtener experimentalmente, adaptando la recomendación RILEM50-FMC (31) a la fábrica. Al establecer una variación lineal de $f_{t}$ con el ángulo $\theta$, es necesario ensayar al menos probetas con dos direcciones de los tendeles respecto a la dirección de la carga. Por el momento no se dispone de un procedimiento para medir directamente. Se asume igual forma para las dos curvas de ablandamiento (resistencia a tracción y cohesión) y que la abertura efectiva de fisura a la que la resistencia a tracción y la cohesión se agotan es igual (véase Figura 2). Esto conduce a las siguientes condiciones para los puntos característicos de las curvas [10].

$$
\omega_{c}=\omega_{\sigma}, \omega_{I c}=\omega_{l \sigma}, c_{0}=f_{t 0} \frac{G_{F}^{I I a}}{G_{F}^{I}}, s_{l c}=s_{I \sigma} \frac{G_{F}^{I I a}}{G_{F}^{I}}
$$

La Figura 4 muestra la superficie de fractura y su evolución bajo condiciones de fisuración en función del pará-

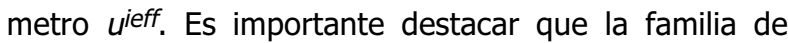
superficies de fractura dependen del ángulo $\theta$. Nótese que para cada estado de daño la superficie hiperbólica de fractura tiene dos ramas y solamente la rama que se extiende hacia los valores negativos de $\sigma$ tiene sentido físico. Nótese igualmente, que para el caso del material completamente dañado (pérdida total de la resistencia a tracción y de la cohesión), la superficie de fractura
The bilinear softening curve for the tensile strength (see Figure 2a) can be determined experimentally from mode I tests following the procedure devised by RILEM 50-FMC (31) for concrete and mortar. For masonry, with a linear variation of $f_{t}$ in relation to $\theta$ angle, at least two directions of the bed joints are needed to be tested. At present, there is no way to measure directly the softening curve for the cohesion. Therefore, we assume that the shape of the two curves (tensile strength and cohesion) is the same and that the effective crack opening at which the tensile strength or cohesion becomes zero is the same (see Figure 2). This leads to the following conditions for the characteristic points of the curve [10].
Figure 4 shows the cracking surface and its evolution under cracking conditions, based on the

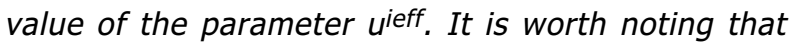
the cracking surfaces family depends on the $\theta$ angle. Note that for each state of damage the hyperbolic cracking surface has two branches and only the branch extending towards negative values of $\sigma$ is physically acceptable. Note also that for fully damaged material (complete loss of tensile strength and cohesion), the cracking surface degenerates 
degenera a una superficie de fricción de Coulomb con un coeficiente de fricción $\mu=\tan \varphi_{f}$, como se muestra en la Figura 4. into a Coulomb friction surface with friction coefficient $\mu=\tan \varphi_{f}$ as shown in Figure 4.

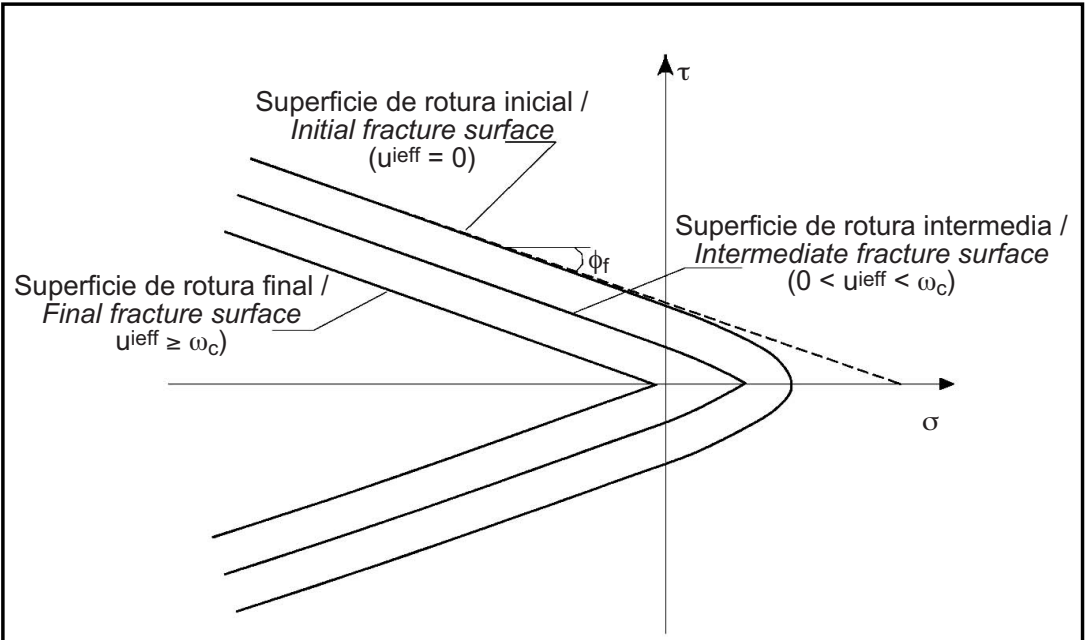

Figura 4. Superficie de rotura y evolución en función del parámetro de ablandamiento uieff. Figure 4. Cracking surface and evolution as function of softening parameter uieff.

La relación $c / f_{t}=G_{F}^{I I a} / G_{F}^{I}$ no puede elegirse de forma arbitraria. De hecho, para que la ecuación $\mathbf{F}(\mathbf{t})=0$ (Ecuaciones [6] y [7]) tenga significado, el factor que se encuentra entre paréntesis no debe ser negativo para cualquier valor de $\sigma \leq f_{t}$ y debe cumplirse [11].

$$
\frac{c}{f_{t}} \geq \tan \phi_{f} \quad y \quad \frac{G_{F}^{I l a}}{G_{F}^{I}} \geq \tan \phi_{f}
$$

\subsection{Regla de flujo y dilatancia}

El modelo requiere la regla de flujo para conocer la evolución de los desplazamientos inelásticos en la zona en proceso de fractura, que se define como [12].
It is worth noting that the ratio $c / f_{t}=G_{F}^{I I a} / G_{F}^{I}$ cannot be selected arbitrarily. Indeed, for the equation $\boldsymbol{F}(\boldsymbol{t})=0$ to be meaningful with $\boldsymbol{F}(\boldsymbol{t})$ given by Equation [6] and [7] the factor in brackets must be non-negative for any $\sigma \leq f_{t}$ and thus we must have [11].

\subsection{Flow rule and dilatancy}

The model is incomplete until the evolution of the inelastic displacements in the fracture process zone is defined. This evolution is specified by means of a flow rule, given by [12].

$$
\dot{\mathbf{u}}^{\mathrm{i}}=\dot{\lambda} \frac{\partial \mathbf{Q}(\mathbf{t})}{\partial \mathbf{t}}=\dot{\lambda} \mathbf{b}
$$

donde $\mathbf{Q}(\mathbf{t})$ es el potencial plástico, b es la normal a la superficie del potencial plástico y $\dot{\lambda}$ es un multiplicador plástico no negativo.

En la fábrica de ladrillo, la tensión tangencial en una fisura genera deslizamiento en la grieta, al mismo tiempo que la grieta se va abriendo debido a la existencia de irregularidades a lo largo del plano de fisura. Este efecto físico recibe el nombre de dilatancia. El ángulo de dilatancia se define como [13]. where $\mathbf{Q}(\mathbf{t})$ is the plastic potential, $\mathbf{b}$ is the normal to the plastic potential surface and $\dot{\lambda}$ is a non-negative plastic multiplier.

In brickwork masonry, the tangential traction in a crack generates crack slip, at the same time as a crack opening due to the irregularities along the crack plane. This physical effect is named dilatancy. The dilatancy angle is defined [13].

$$
\tan \phi_{d}=\frac{\dot{u}_{i n}}{\dot{u}_{i t}}
$$


donde $\phi_{d}$ es el ángulo de dilatancia, $\dot{u}_{i n}$ y $\dot{u}_{i t}$ son los incrementos de desplazamiento inelásticos en las direcciones normal y tangencial a la fisura, respectivamente. $\phi_{d}$ coincide con el ángulo formado por la superficie potencial y la parte negativa del eje $\sigma$ (véase Figura 5). where $\phi_{d}$ is the dilatancy angle, $\dot{u}_{i n}$ and $\dot{u}_{i t}$ are the incremental inelastic displacements in normal and tangential directions to the crack, respectively. $\phi_{d}$ coincides with the angle formed by the potential surface and the negative part of the $\sigma$ axis (see Figure 5).

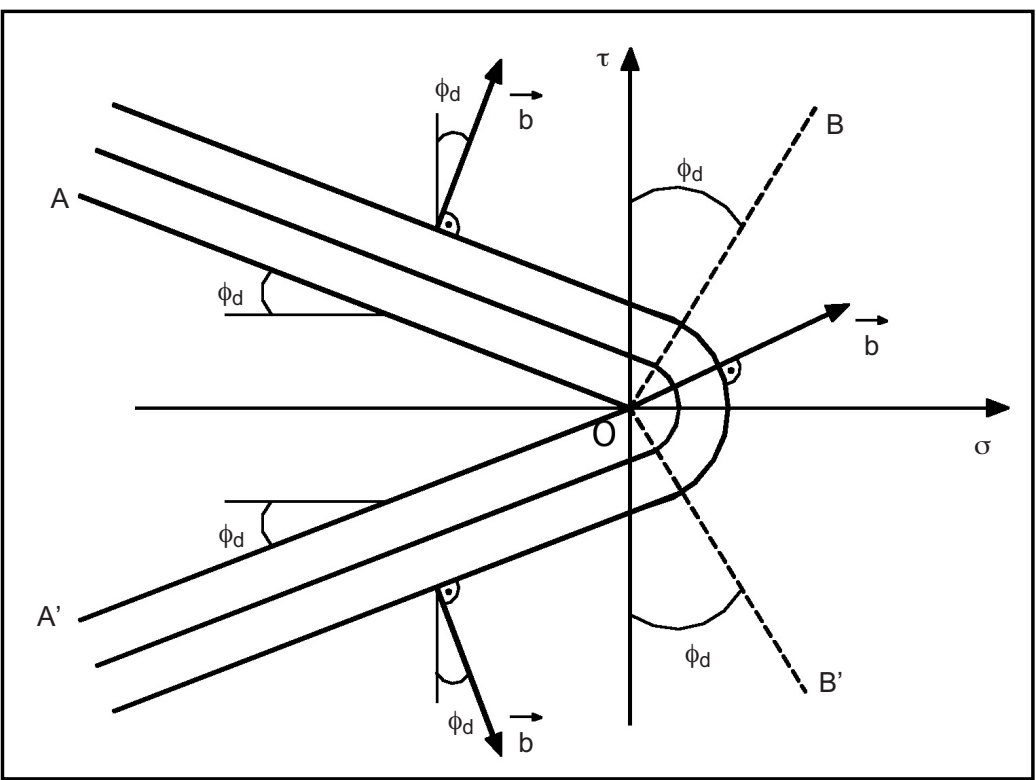

Figura 5. Curvas de potencial plástico para un ángulo de dilatancia $\phi_{d}$ dado. Figure 5. Plastic potential curves for a fixed dilatancy angle $\phi_{d}$.

Se asume que la dilatancia también depende del nivel de daño a través de $u^{\text {ieff, }}$ y se adopta una curva lineal (23) [14].
The dilatancy is also assumed to depend on the damage level through uieff. A linear curve has been adopted (23) [14].

$$
\phi_{d}=\left\{\begin{array}{ll}
\phi_{d 0}\left(1-\frac{u^{i e f f}}{u_{c d}}\right) & , \forall u^{i e f f}<u_{c d} \\
0 \quad, \forall u^{i e f f} \geq u_{c d}
\end{array}\right\}
$$

donde $\phi_{d 0}$ es el valor inicial del ángulo de dilatancia y $u_{c d}$ es el desplazamiento inelástico crítico de fisura a partir del cual la fisura cesa de mostrar el efecto de dilatancia.

Cuando la tensión de tracción $\sigma$, tiene un valor predominante sobre la tensión tangencial $\tau$, la dirección normal al potencial plástico $(\mathbf{Q}=$ cte $)$ no está definida. En este caso se adopta la dirección de retorno al origen de tensiones, la que divide el espacio de tensiones en dos partes, como se muestra en la Figura 5. De esta forma se tiene que la formulación propuesta utiliza un modelo de plasticidad no asociada, en el que las direcciones normales a la superficie de fractura y al potencial plástico son diferentes.

\subsection{Integración de las ecuaciones diferenciales}

La integración de las ecuaciones incrementales está basada en el esquema estándar de backward-Euler (para where $\phi_{d 0}$ is the initial value of the dilatancy angle and $u_{c d}$ is the critical inelastic crack displacement after which the crack ceases to exhibit the dilatancy effect.

When traction stress $\sigma$, is predominant over the tangential stress $\tau$, the direction normal to the plastic potential $(\mathbf{Q}=c t e)$ is not defined. Consequently, in this case the return direction to the origin of stresses is adopted, which divides the stresses space into two parts, as is shown in Fig. 5. It should be pointed out that this is a non-associative plasticity approach, where normal directions to cracking surface and plastic potential are different.

\subsection{Integrating the rate equations}

The integration of the rate equations is based on the standard backward Euler scheme (see (23) for details). 
más detalles ver (23)). Una vez diferenciadas las ecuaciones 3 y 4 y con la Ecuación 12 , el vector $\dot{t}$ se puede expresar [15].
The Equations 3 and 4 are differentiated and with Equation $12 \dot{t}$ is obtained [15].

$$
\dot{\mathbf{t}}=\mathbf{K}_{e}(\dot{\mathbf{u}}-\dot{\lambda} \mathbf{b}) \Rightarrow \Delta \mathbf{t}=\mathbf{K}_{e} \Delta \mathbf{u}-\mathbf{K}_{e} \Delta \lambda \mathbf{b}
$$

Para un determinado estado en el paso $n$, el vector tracción $\mathbf{t}_{n}$ y el parámetro de ablandamiento uieff son conocidos. Si en el paso $n$ la fisura crece debe satisfacerse la ecuación de la superficie de fractura: $\mathbf{F}\left(\mathrm{t}_{n}, u_{n}^{\text {ieff }}\right)=0$.

Se adopta un incremento de desplazamiento relativo entre las dos caras de la fisura $\Delta \mathbf{u}_{n}=\mathbf{u}_{n+1}-\mathbf{u}_{n,}$ y se alcanza un nuevo estado de tracción, $\mathbf{t}_{n+1}$, que se calcula como sigue [16].
For a given state in the $n$-th step, the traction vector $\mathbf{t}_{n,}$ and the softening parameter $u^{\text {ieff, }}$ are known. Let us assume that in $n$ step, the crack is growing, so the cracking surface equationis satisfied: $\mathbf{F}\left(\mathrm{t}_{n}, u_{n}^{\text {ieff }}\right)=0$.

An incremental relative displacement between crack faces is adopted, $\Delta \mathbf{u}_{n}=\mathbf{u}_{n+1}-\mathbf{u}_{n}$, and a the new traction state, $\mathbf{t}_{n+1}$, is calculated as follows [16].

$$
\mathbf{t}_{e}=\mathbf{t}_{n}+\mathbf{K}_{e} \Delta \mathbf{u}
$$

donde $\mathbf{t}_{e}$ es un nuevo vector tracción, obtenido a partir de un predictor elástico. Si a su vez la fisura crece en el paso $n+1$, la ecuación de la superficie de fractura debe satisfacerse, $\mathbf{F}\left(\mathrm{t}_{n+1}, u_{n+1}^{\text {ieff }}\right)=0$, y el vector tracción, $\mathrm{t}_{n+1}$, se obtiene a partir de $t_{e}$ adoptando el corrector inelástico [17].

$$
\mathbf{t}_{n+1}=\mathbf{t}_{e}+\Delta \lambda_{n} \mathbf{K}_{e} \mathbf{b}_{n}
$$

donde $\Delta \lambda_{n} \mathbf{K}_{e} \mathbf{b}_{n}$ es el corrector inelástico, $\mathbf{K}_{e}$ es el tensor elástico y $\mathbf{K}_{\mathbf{e}} \mathbf{b}_{\boldsymbol{n}}$ es la dirección del vector de retorno al potencial plástico $\left(\mathbf{Q}=\right.$ cte). $\Delta \lambda_{n}$ se obtiene a partir de la condición de que la ecuación de la superficie de fractura debe satisfacerse en el paso $n+1$ [18]. where $\mathbf{t}_{e}$ is a new traction vector, obtained from an elastic predictor. If the crack is growing in the $n+1$ state the cracking surface equation should be satisfied, $\mathbf{F}\left(\mathrm{t}_{n+1}\right.$, $\left.u_{n+1}^{\text {ieff }}\right)=0$, and the traction vector, $\mathrm{t}_{n+1}$, is obtained from $\mathrm{t}_{e}$, adopting the inelastic corrector [17].

$$
\mathbf{F}\left(\mathbf{t}_{n+1}, u_{n}^{\text {ieff }}\right)=\mathbf{F}\left(\mathbf{t}_{e}+\Delta \lambda_{n} \mathbf{K}_{e} \mathbf{b}_{n}, u_{n}^{\text {ieff }}\right)=0
$$

que expresada como una función de la resistencia a tracción y la cohesión queda [19]. where $\Delta \lambda_{n} \mathbf{K}_{\mathbf{e}} \mathbf{b}_{\boldsymbol{n}}$ is the inelastic corrector, $\mathbf{K}_{\mathbf{e}}$ is the elastic tensor and $\mathbf{K}_{\mathbf{e}} \mathbf{b}_{\boldsymbol{n}}$ is the return direction vector to the plastic potential $(\mathbf{Q}=c t e) . \Delta \lambda_{n}$ is obtained since the cracking surface equation must be satisfied in the $n+1$ state [18].

which expressed as a function of traction strength and cohesion gives [19].

$$
\mathbf{F}\left(\mathbf{t}_{n+1}, c_{n}(\theta), f_{t n}(\theta)\right)=0
$$

donde $c_{n}(\theta)$ y $f_{\text {tn }}(\theta)$ son la cohesión y la resistencia a tracción en el paso $n$. A continuación se actualizan los parámetros implicados en el procedimiento [20]. where $c_{n}(\theta)$ and $f_{\text {tn }}(\theta)$ are the cohesion and traction strength at $n$ state. Then, the parameters involved in the procedure are actualised [20].

$$
\begin{gathered}
\Delta u_{n}^{\text {ieff }}=\left\|\Delta \mathbf{u}_{n}^{i}\right\|=\Delta \lambda_{n}\left\|\mathbf{b}_{n}\right\| \Rightarrow u_{n+1}^{\text {ieff }}=u_{n}^{\text {ieff }}+\Delta u_{n}^{\text {ieff }} \\
f_{t_{n+1}}(\theta)=f_{t}\left(u_{n+1}^{\text {ieff }}, \theta\right) ; c_{n+1}(\theta)=c\left(u_{n+1}^{\text {ieff }}, \theta\right) ; \phi_{d_{n+1}}(\theta)=\phi_{d}\left(u_{n+1}^{\text {ieff }}, \theta\right) ; \\
\mathbf{b}_{n+1}=\mathbf{b}\left(u_{n+1}^{\text {ieff }}, \theta\right)
\end{gathered}
$$

La resistencia a tracción $f_{t}(\theta)$, la cohesión $c_{n}(\theta)$, la dirección de retorno $\mathbf{K}_{\mathbf{e}} \mathbf{b}$ y el ángulo de dilatancia $\phi_{d}$
It is worth noting that the traction strength, $f_{t}(\theta)$, the cohesion, $c_{n}(\theta)$, the return direction, $\mathbf{K}_{\mathbf{e}} \mathbf{b}$, and the 
empleados en la Ecuación 18 durante el paso $n$ no son actualizados al paso $n+1$. Esto se debe a que el valor del parámetro de ablandamiento, $u^{\text {ieff, }}$ se obtiene una vez conocido el incremento del multiplicador plástico, $\Delta \lambda$. Esto conduce a un proceso iterativo que finaliza cuando la corrección inelástica necesaria es inferior a un valor prefijado.

Se ha desarrollado un elemento de intercara para incorporar este modelo en el código de elementos finitos comercial ABAQUS ${ }^{\complement}$. Más detalles referentes a la implementación del elemento finito se pueden encontrar en $(8,23)$. Para el procedimiento computacional se ha utilizado un algoritmo de longitud de arco y no se han encontrado especiales problemas de convergencia en el cálculo.

Para simplificar los cálculos, se ha adoptado comportamiento elástico lineal para el material fuera de la fisura, aunque esta simplificación puede eliminarse.

\section{RESUMEN DEL PROGRAMA EXPERIMENTAL}

Para la contrastación y verificación del modelo de cálculo propuesto se han empleado algunos de los resultados de los ensayos presentados por los autores (1). Se trata de los ensayos de fractura en modo mixto realizados con probetas PCDE. Como se indica en (1) los ensayos no pretenden ser una modelización a pequeña escala de la fábrica real. Las probetas a escala captan las características esenciales de fábrica $(1,10)$ con un coste experimental razonable. El factor de escala $1 / 4$ permite ensayar probetas con un número representativo de unidades de ladrillo macizo, de forma que la aproximación mesoscópica sea adecuada.

Las probetas de fábrica de ladrillo a escala estaban constituidas por ladrillos cerámicos macizos, de dimensiones $48 \times 24 \times 10 \mathrm{~mm}^{3}$, obtenidos por corte a partir de ladrillos macizos comerciales. El mortero estaba compuesto por cemento CEM I 42,5 N (Tipo I ASTM) y arena silícea de $1 \mathrm{~mm}$ de tamaño máximo. El espesor de los tendeles era $3 \mathrm{~mm}$. La Tabla 1 muestra las propiedades mecánicas de los materiales constituyentes de la fábrica.

Con el fin de medir las propiedades mecánicas de la fábrica, en especial las de fractura, se ensayaron paneles de fábrica con los tendeles orientados en tres direcciones: horizontal, vertical y a $45^{\circ}$. La energía de fractura se midió de acuerdo a la recomendación RILEM 50-FMC (31), adaptada a la fábrica. La Tabla 2 muestra las propiedades mecánicas de la fábrica medidas para las tres orientaciones de los tendeles. dilatancy angle, $\phi_{d}$, used in Equation 18 corresponding to the $n$ state are not actualised to the $n+1$ state. This occurs because the value of the softening parameter, uieff, obtained once the increment of the plastic multiplier, $\Delta \lambda$, is known. This leads to an iterative process that ends when the inelastic correction is below a prefixed value.

An interface element was developed to incorporate the model in the finite element code ABAQUS ${ }^{\circ}$. Details regarding the finite element implementation are found in $(8,23)$. An arc length algorithm was adopted for computational procedure and no special difficulties were found in achieving a convergent solution.

To simplify the computations, the bulk behaviour is commonly assumed to be linear-elastic and anisotropic, although this approximation can be relaxed if necessary.

\section{OVERVIEW OF THE EXPERIMENTAL PROGRAM}

To check the model, the series of mixed fracture tests (1) were adopted. The double-edge notched specimen (DENT) tests were numerically simulated. This experimental programme was not intended to be a small scale modelling of real masonry walls. The aim of using scaled specimens is to capture the essentials of the mixed mode fracture of masonry while maintaining a reasonable experimental cost. A scale factor of $1 / 4$ was chosen, both to avoid difficulties in modelling the joint thickness, and have a representative number of bricks units in masonry specimens.

Masonry specimens were made with small-scale bricks of $48 \times 24 \times 10 \mathrm{~mm}^{3}$ were cut from commercial solid clay bricks. A single mortar mixture was used to cast the specimens. It was composed of Portland cement CEM I $42.5 \mathrm{~N}$ (ASTM Type I) and siliceous sand of $1 \mathrm{~mm}$ maximum size, compatible with the scaled-down thickness of the joints of $3 \mathrm{~mm}$. Table 1 shows the mechanical properties of the constituents of the masonry.

To obtain the fracture mechanical properties of the brick masonry, the prisms of brick masonry were tested in accordance with RILEM 50-FMC (31) for the energy fracture measurement. Masonry prisms with horizontal, 45 degrees and vertical bed joints were tested. Table 2 summarises the results. 
Tabla 1 / Table 1

Propiedades mecánicas de los materiales que constituyen la fábrica.

Mechanical properties of the constituent elements of brick masonry.

\begin{tabular}{|c|c|c|}
\hline Elemento / Element & $G_{F}(\mathbf{N} / \mathbf{m})^{\mathbf{a}}$ & $f_{t}(\mathbf{M P a})^{\mathbf{b}}$ \\
\hline Ladrillo / Brick & 107 & 7.6 \\
\hline Mortero / Mortar & 86 & 5.4 \\
\hline Intercara / Interface & 10 & - \\
\hline
\end{tabular}

a $G_{F}:$ energía de fractura / specific fracture energy.

b $f_{t}$ : resistencia a tracción / tensile strength.

Tabla 2 / Table 2

Propiedades mecánicas de la fábrica.

Mechanical properties of brick masonry.

\begin{tabular}{|c|c|c|c|}
\hline Orientación / Orientation & $\boldsymbol{G}_{F}(\mathbf{N} / \mathbf{m})^{\mathbf{a}}$ & $\boldsymbol{f}_{\boldsymbol{t}}(\mathbf{M P a})^{\mathbf{b}}$ & $\left.\boldsymbol{b}^{\mathbf{G P a}}\right)^{\mathbf{c}}$ \\
\hline Horizontal & 75 & 5.8 & 38 \\
\hline $45^{\circ}$ & 54 & 4.1 & 28 \\
\hline Vertical & 33 & 2.4 & 18 \\
\hline
\end{tabular}

a $G_{F}$ : energía de fractura / specific fracture energy.

b $f_{t}$ : resistencia a tracción / tensile strength.

c E: módulo de elasticidad / Young's modulus.

La Figura 6 muestra un esquema del dispositivo de ensayo, la instrumentación empleada y la geometría y dimensiones de las probetas. Las dimensiones de las probetas ensayadas eran $112,5 \times 150 \times 26,2 \mathrm{~mm}^{3}$, con dos entallas simétricas de $37,5 \mathrm{~mm}$ de longitud cada una. El final de las entallas se encontraba dentro de un ladrillo para no favorecer ninguna dirección en el inicio de la fisuración. El ensayo consistió en aplicar una carga de compresión sobre la mitad de la probeta. La carga se aplicó con dos placas de chapa rectificada para garantizar el adecuado reparto de carga. Entre la chapa y la probeta se dispuso una lámina de teflón (PTFE) con el fin de eliminar el rozamiento. Se ensayó probetas con los tendeles horizontales, verticales y orientados a $45^{\circ}$. La Figura 7
Figure 6 shows the testing arrangement, geometry, dimensions and instrumentation of the tests. The dimensions of the specimens were $112.5 \times 150 \times 26.2$ $\mathrm{mm}^{3}$. Two symmetrical notches of $37.5 \mathrm{~mm}$ were performed. The end of both notches was in a brick unit in order not to favour any direction at the onset of cracking. The mixed mode fracture test in masonry carried out in this work consisted in apply a compression load on one half specimen of the double-edge notched specimen described above. Two ground and smooth steel plates were placed between the machine platens and the upper and bottom faces of the specimen to assure a good spread of the load. Besides, to eliminate the friction between the steel plate and the brickwork a

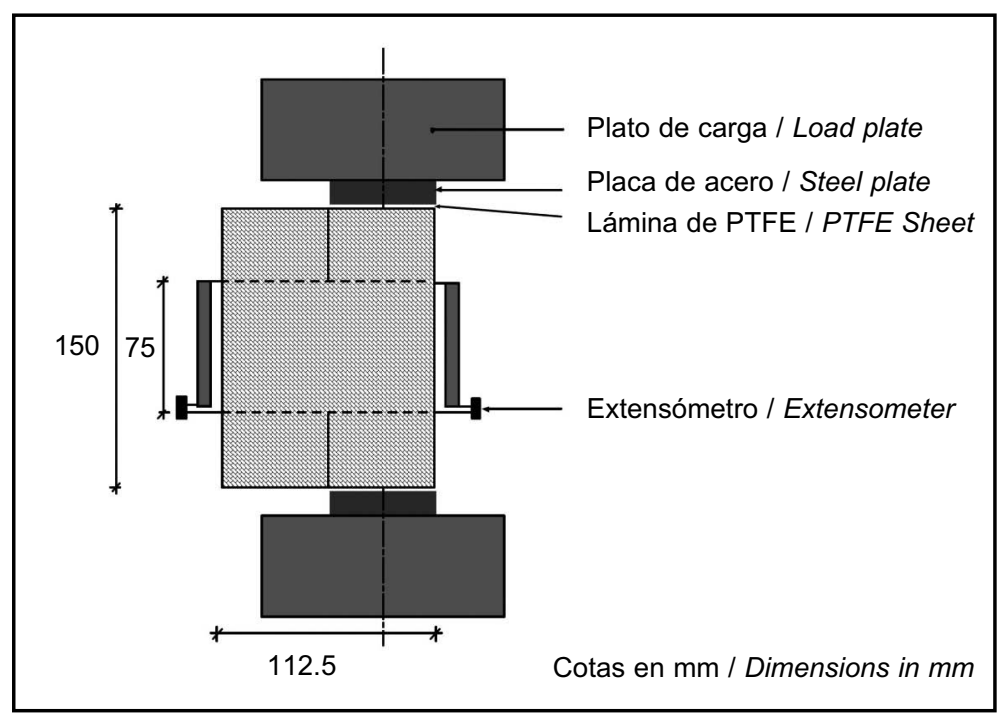

Figura 6. Esquema del ensayo, geometría y dimensiones de la probeta compacta con doble entalla (PCDE) e instrumentación empleada. Figure 6. Testing arrangement, geometry, dimensions and instrumentation of the compact double-edge notched (DENT) specimen. 
muestra una probeta con los tendeles horizontales durante el ensayo.

Para distinguir e identificar las fisuras generadas por tensiones de tracción y cortante se cubrieron las caras de las probetas con una capa de fluoresceína (este producto cambia de color cuando se abre fisura y el agua de saturación de la probeta de fábrica fluye al exterior). La Figura 8 muestra la foto de una probeta agrietada tras el ensayo. Las ref. $(1,8)$ recogen de forma detallada la campaña experimental y sus resultados.

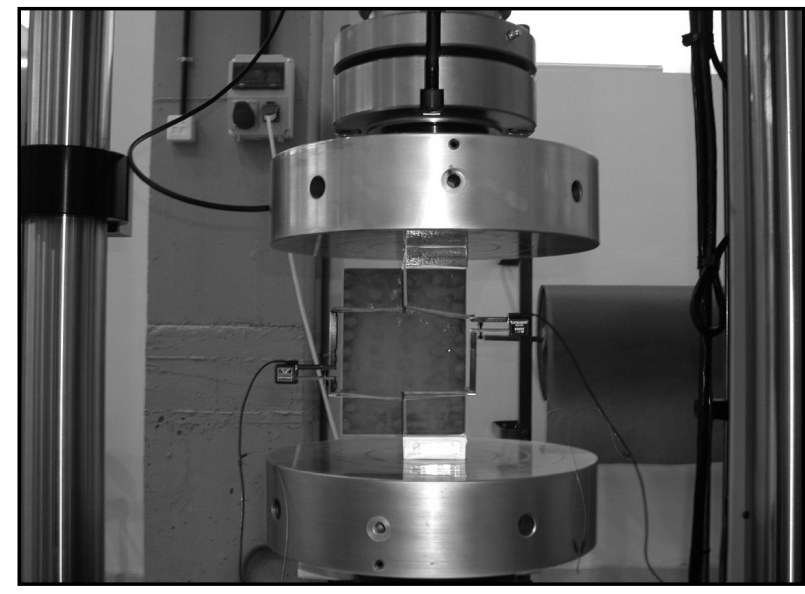

Figura 7. PCDE con los tendeles a $0^{\circ}$ durante el ensayo. Figure 7. DENT specimen with bed joints at 0 degrees, during testing.

\section{RESULTADOS Y DISCUSIÓN}

Con el fin de comprobar el buen comportamiento del modelo propuesto se han reproducido los ensayos presentados en el apartado anterior. La trayectoria de las grietas se calculó mediante Mecánica de Fractura Elástica Lineal y posteriormente se incorporó en la geometría de la malla de elementos finitos. La Figura 9 muestra los caminos de grieta experimentales para las tres orientaciones de los tendeles de las probetas ensayadas y su predicción numérica. La predicción numérica es una aproximación suficientemente ajustada de la trayectoria de fisura, válida para las tres orientaciones de los tendeles. En este sentido, conviene destacar el hecho de que la fábrica muestra una mayor dispersión experimental que otros materiales cuasi frágiles, como el hormigón o el mortero. El uso de una única trayectoria de fisura numérica, y por lo tanto una única malla de elementos finitos, conduce a un ahorro importante en el tiempo de cálculo del proceso. La Figura 10 muestra la malla de elementos finitos utilizada para estudiar la fractura en modo mixto de las probetas de fábrica de ladrillo.
Polytetrafluoro-ethylen (PTFE) sheet was inserted. Figure 7 shows a specimen with horizontal bed joints during testing.

To distinguish and identify the mixed mode cracks, the faces of the specimens were covered with a thin film of fluoresceine (this product changes its colour when the crack opens and the water contained inside goes out of the masonry). Figure 8 shows a photo of a cracked specimen after tested. Detailed information about specimen preparation and experimental procedure may be found in $(1,8)$.

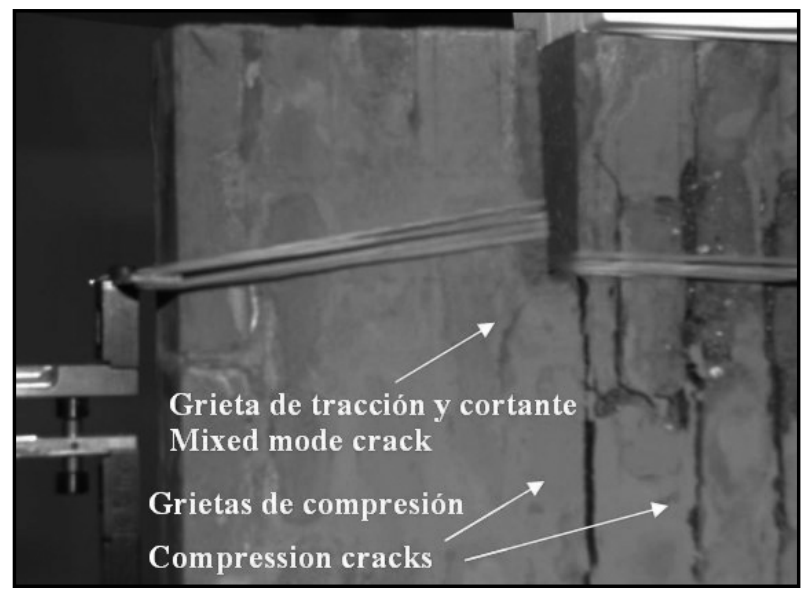

Figure 8. Trayectoria de la grieta de tracción y cortante en uno de los ensayos después del ensayo.

Figure 8. Tensile stress and shear crack path on a tested specimen.

\section{RESULTS AND DISCUSSION}

In order to check the good behaviour of the numerical model described in this work, the presented numerical procedure is used to reproduce the experimental results. The crack path was calculated by means of LEFM and incorporated into the finite element mesh. Figure 9 shows the experimental and the numerical prediction of the crack paths for the three orientations of the bed joints of the tested specimens. The numerical prediction is a sufficiently accurate approximation of the crack path, valid for the three orientations of the bed joints. In this sense, it is noticeable that masonry exhibits a wider experimental scatter than other quasi-brittle materials such as mortar and concrete. The use of a single numerical crack path, and then only one finite element mesh, leads to a less time consuming calculation procedure. Figure 10 shows a finite element mesh used to study the mixed mode fracture of the brickwork masonry specimens. 


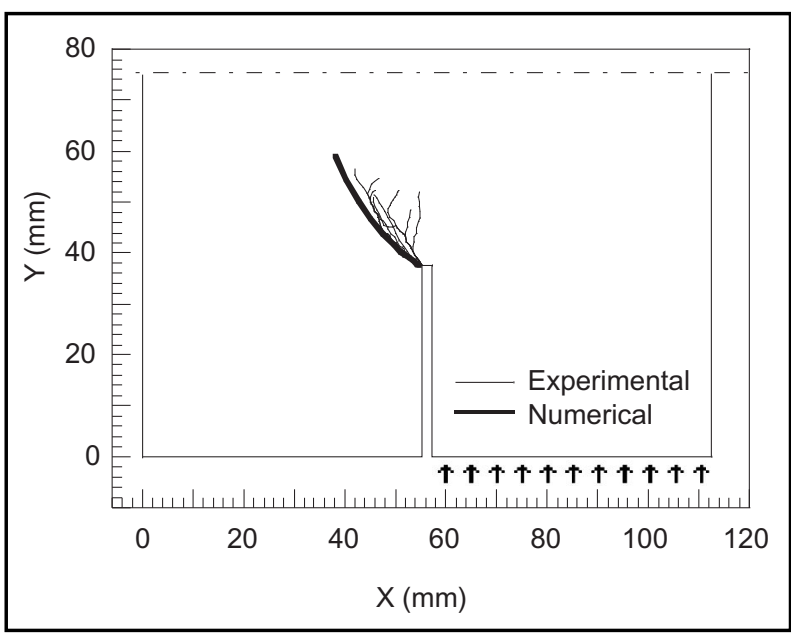

Figura 9. Trayectorias experimentales y predicción numérica de las grietas de tracción y cortante.

Figure 9. Experimental records and numerical prediction of the the mixed mode crack paths.

En la trayectoria de fisura se incorporaron los elementos de intercara con el modelo de fisura cohesiva. Se emplearon las propiedades del material medidas experimentalmente (véase Tabla 2). Los parámetros de fractura en modo II que, como se ha indicado no se pueden medir experimentalmente, se estimaron de acuerdo con $(8,23)$ y se muestran en la Tabla 3. Los valores adoptados para los ángulos de fricción y de dilatancia fueron: $\phi_{f}=0,5 \mathrm{rad}$ y $\phi_{d 0}=0,3 \mathrm{rad}$.

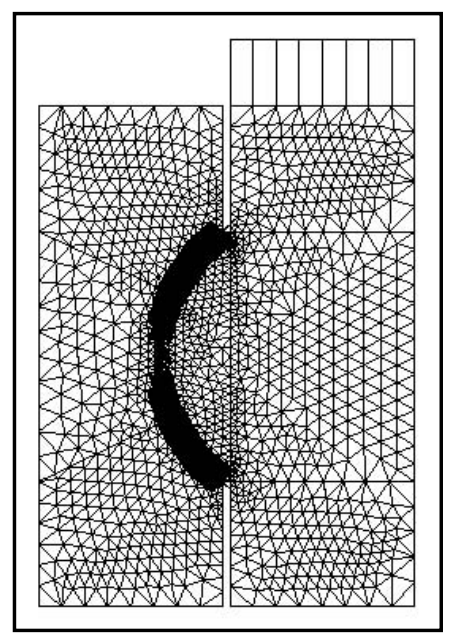

Figure 10. Malla de elementos finitos utilizada en la simulación del ensayo PCDE.

Figure 10. Finite element mesh for numerical simulation of DENT test.

In the crack path were incorporated the interface elements with the cohesive crack model. The experimentally measured fracture mode I properties were adopted for the simulation (see Table 2). The mode II fracture parameters were estimated in accordance with $(8,23)$, Table 3 shows these parameters. The following values for friction angle and the dilatancy angle, were adopted: $\phi_{f}=0.5$ rad and $\phi_{d 0}=0.3 \mathrm{rad}$.

Tabla 3 / Table 3

Valores estimados de los parámetros de fractura en modo II para la fábrica de ladrillo $(8,12)$. Estimated mode IIa fracture parameters for brick masonry $(8,12)$.

\begin{tabular}{|c|c|c|}
\hline Elemento / Element & $G_{F}^{\| l a}(\mathbf{N} / \mathbf{m})^{\mathbf{a}}$ & $c\left(\mathbf{N} / \mathbf{m m}^{2}\right)^{\mathbf{b}}$ \\
\hline Horizontal / Horizontal & 77.6 & 6 \\
\hline $45^{\circ}$ & 65.8 & 5 \\
\hline Vertical / Vertical & 55 & 4 \\
\hline
\end{tabular}

a $G_{F}^{I I a}$ : energía de fractura en modo IIa / mode IIa specific fracture energy.

b c: cohesión / cohesion.

Las Figuras 11a), 11c) y 11e) muestran las curvas experimentales y la predicción numérica de la carga frente al alargamiento registrado por el extensómetro acoplado en la parte no cargada de la probeta (extensómetro de la izquierda en la Figura 6) para las probetas con las tres orientaciones de los tendeles. Las curvas presentan una primera parte lineal seguida de una rama curva, en la que se pierde dicha linealidad, y retorna con desplazamientos decrecientes conforme se incrementa la carga. El retorno de la curva está producido por el inicio de la fisuración bajo tensiones normales y tangenciales y su posterior propagación a partir de las entallas, lo cual reduce la carga transmitida por el ligamento entre las partes cargada y descargada de la
Figures 11a), 11c) and 11e) show the experimental curves and the numerical prediction of the load versus lengthening recorded by the extensometer placed on the load-free half part of the specimen (left extensometer in Figure 6) for the specimens with three angles between the direction of the applied load and the bed joints. The nucleation and growth of the cracks is shown in the curves by the loss of linearity and a marked drawing back, falling the displacements even almost null values. The crack growth moderates the load transference from the loaded to the load-free part of the specimen and leads to a reduction in the lengthening of the load-free part. Cohesive crack model accurately predicts the behaviour of the load 
probeta. La carga pico del ensayo está gobernada por el fallo por compresión de la parte cargada de la probeta. El modelo de fisura cohesiva predice de forma adecuada el comportamiento de la carga frente al alargamiento de la parte no cargada de la probeta en todos los casos estudiados.

Las Figuras 11b), 11d) y 11f) muestran las curvas experimentales y la predicción numérica de la carga aplicada frente al acortamiento registrado por el extensómetro acoplado en la mitad cargada de la probeta (extensómetro derecho en la Figura 6) para las probetas con las tres orientaciones de los tendeles. La predicción numérica, corresponde a los resultados del modelo elastoplástico de compresión proporcionado por ABAQUS ${ }^{\complement}$. La vuelta atrás de las curvas en la Figura 11f) está motivada por el pandeo de la última hilada vertical de la probeta al final del ensayo. Los resultados conseguidos, como puede apreciarse, no son muy ajustados, sin embargo debe recordarse que la modelación de la fábrica en compresión queda fuera de los objetivos de este trabajo.

\section{COMENTARIOS FINALES Y CONCLUSIONES}

En este trabajo se propone un modelo de fisura cohesiva para la fractura en modo mixto de fábrica. El modelo es una extensión a materiales anisótropos del modelo cohesivo desarrollado en $(23,24)$ para fractura en modo mixto de hormigón (material isótropo). El procedimiento numérico utiliza la Mecánica de Fractura Elástica Lineal para predecir la trayectoria de fisura, tiene en cuenta la anisotropía del material, y ha sido implementado en un código de elementos finitos comercial con una subrutina de usuario.

El modelo se ha contrastado con los resultados experimentales de los ensayos de fractura en modo mixto de probetas PCDE de fábrica a escala. El procedimiento de cálculo predice adecuadamente tanto la trayectoria de la grieta, como las curvas de la carga frente al alargamiento experimental registrado por el extensómetro colocado en la mitad no cargada de la probeta, que es el que está gobernado por la fractura en modo mixto. Además, confirma los resultados experimentales que muestran la intercara mortero-ladrillo como la parte más débil, y que las probetas con la orientación de los tendeles a $45^{\circ}$ conducen a las cargas de rotura más bajas.

El modelo propuesto consigue un equilibrio entre exactitud y simplicidad, proporcionando una herramienta útil en la predicción de la fractura de grandes elementos estructurales cuando una única fisura macroscópica, o un número finito de ellas, es el principal mecanismo de versus lengthening on the load-free half of the specimen in all cases.

Figures 11b), 11d) and 11f) show the experimental envelope and the numerical prediction of the load versus shortening recorded by the extensometer placed on the loaded half of the specimen (right extensometer in Figure 6) for the specimens with three angles between the direction of the applied load and the bed joints. The numerical prediction correspond the results of the elastoplastic model for compression supplied by ABAQUS ${ }^{\circledR}$. The obtained results are not very accurate. Numerical modelling of the pre and post peak behaviour under compression loading would need an adequate compression model, however it is worth noting that this is beyond the scope of this work.

\section{FINAL COMMENTS AND CONCLUSIONS}

A cohesive crack numerical model for mixed mode fracture of masonry has been proposed. The model is an extension to anisotropic materials of the cohesive model developed by $(23,24)$ for mixed mode fracture of concrete (isotropic material). The numerical procedure uses LEFM crack prediction, takes into account the anisotropy of the material, and has been implemented in a commercial finite element code by means of a user subroutine.

The numerical model correctly predicts the experimental results. Numerical simulation based on the LEFM crack path prediction provides a good fit of the load versus lengthening experimental curves recorded by the extensometer placed on the load-free half part of the specimen. Numerical and experimental results confirm that the interface brick-mortar is the weakest part of the masonry. The lowest load failure was reached on the specimens whose orientation of the brick layers was 45 degrees.

The proposed model procedure reaches a balance between accuracy and simplicity, and provides a helpful tool in predicting the fracture of large masonry structural elements when a single macro-crack, or finite number of them, is the main failure mechanism. The presented model does not 


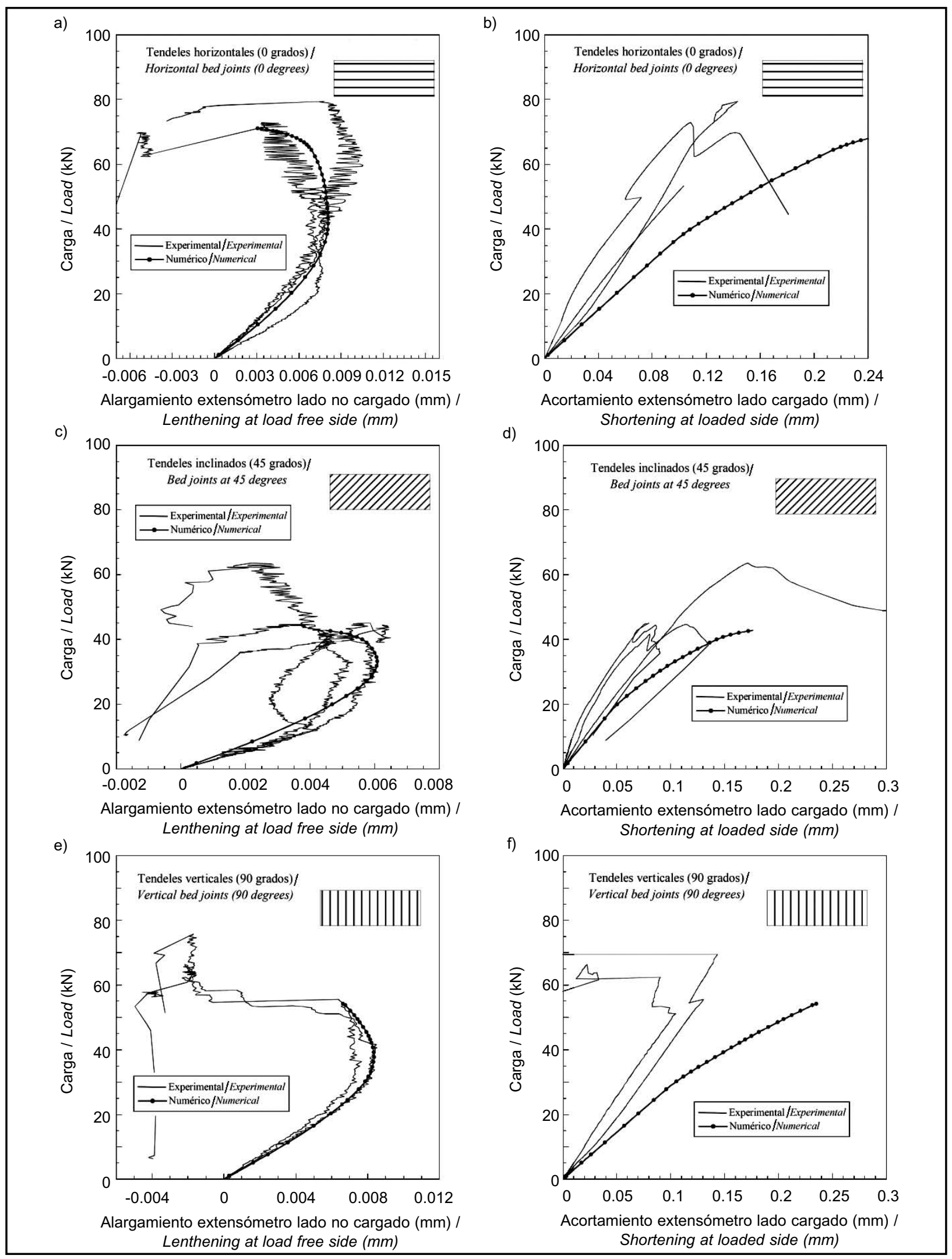

Figura 11. Registros experimentales y predicción numérica de la carga aplicada frente al alargamiento del extensómetro situado en el lado no cargado: a), c) y e), y carga aplicada frente al acortamiento del extensómetro situado en el lado cargado: b), d) y f), para las probetas con los tendeles horizontales, a 45 grados y verticales, respectivamente.

Figure 11. Experimental records and numerical prediction of applied load versus elongation of the strain gauge positioned in the unloaded area: a), c) y e), and applied load versus shortening of the strain gauge positioned in the loaded area: b), d) y f), for specimens with horizontal, $45^{\circ}$ and vertical bed joints. 
fallo. El modelo presentado no contempla la microfisuración distribuida en la estructura.

Los resultados obtenidos indican que el uso de modelos cohesivos para el estudio de la fisuración de la fábrica es muy prometedor. Desde el punto vista ingenieril, el empleo de modelos que emplean propiedades de la fábrica medidas con ensayos normalizados constituyen una herramienta útil para la predicción del comportamiento de la fábrica y la interpretación de los procesos de deterioro que conllevan fisuración.

\section{AGRADECIMIENTOS}

Los autores desean agradecer al Ministerio de Ciencia e Innovación la concesión del proyecto BIA2008-03523 y al Ministerio de Fomento el proyecto MFOM 01/7. include distributed cracking or damage in the structure and applies in the case of a macro-crack occurring.

The described numerical model and the experimental results emphasise that the cohesive crack models, taking into account the anisotropy of the masonry, are promising tools in the simulation of the mixed mode fracture of the masonry in large structural elements. For engineering purposes, the averaging of the masonry properties provides rough but sufficiently precise data for cohesive modelling. For small masonry elements, a more detailed analysis of fracture micro-mechanisms, especially interface brick-mortar interaction, is required.

\section{ACKNOWLEDGEMENTS}

The authors gratefully acknowledge financial support for this research by the Ministerio de Ciencia e Innovación under grant BIA2008-03523 and by the Ministerio de Fomento under grant MFOM 01/07.

\section{BIBLIOGRAFÍA / BIBLIOGRAPHY}

(1) Reyes, E.; Casati, M. J.; Gálvez, J. C.: "Estudio experimental de la fisuración de la fábrica de ladrillo bajo solicitaciones de tracción y cortante en modelos reducidos", Mater. Constucc., vol. 58 (2008), pp. 69-83.

(2) Steward, M. G.; Lawrence, S.: "Structural reliability of masonry walls in flexure", Masonry Int. vol.15 (2002), pp. 48-52.

(3) Lorenço, P. B.: Computational strategies for masonry structures, Ph.D. Thesis, p. 211, Delft, The Netherlans (1996).

(4) Lorenço, P. B.; Rots, J.; Blaauwendraad, J.: "Continuum model for masonry: parameter estimation and validation", ASCE J. Struct. Eng., vol.124 (1986), pp. 642-652.

(5) Jukes, P., Riddintong, J. R.: "The failure of brick triplet test specimens", Masonry Int., vol. 15, no 1 (2001), pp. 30-33.

(6) Bosiljkov, V.; Zarnic, R.; Kralj, V.; Pande, G. N.: "Experimentally-based computational modelling of masonry", Computer Methods in Structural Masonry, 4 (1998), pp. 103-110, E\&FN Spon, New York.

(7) Lourenço, P. B.; Ramos, L. F.: "Characterization of cyclic behaviour of dry masonry joints, ASCE Journal of Structural Engineering, vol. 130, no 5 (2004), pp. 779-786. doi:10.1061/(ASCE)0733-9445(2004)130:5(779)

(8) Reyes, E.: Rotura de la fábrica de ladrillo bajo solicitaciones de tracción y cortante, Tesis Doctoral, Universidad de Castilla La Mancha (2004).

(9) Van der Pluijm, R.: Out of plane bending of masonry behaviour and strength, Ph.D. Thesis, 259 pp., Delft, The Netherlands (1999).

(10) Guinea, G. V.; Hussein, G.; Elices, M.; Planas, J.: "Micromechanical modelling of brick-masonry fracture", Cem. Concr. Res., vol. 30 (2000), pp. 731-737. doi:10.1016/S0008-8846(00)00228-3

(11) Reyes, E.; Gálvez, J. C.; Casati, M. J.; Cendón, D. C.; Sancho, J. M.; Planas, J.: "An embedded cohesive crack model for finite element analysis of brickwork masonry fracture", Engineering Fracture Mechanics, vol. 76 (2009), pp. 1930-1944. doi:10.1016/j.engfracmech.2009.05.002

(12) Reyes, E.; Casati, M. J.; Gálvez, J. C.: "Cohesive crack model for mixed mode fracture of brick masonry", Int. Journal of Fracture, vol. 151 (2008), pp. 29-55. doi:10.1007/s10704-008-9243-1

(13) Fathy, A. M.; Planas, J.; Sancho, J. M.: "A numerical study of masonry cracks", Eng. Failure Analysis, vol. 16 (2009), pp. 675-689. doi:10.1016/j.engfailanal.2008.02.011

(14) Rots, J. G.: "Numerical simulation of cracking in structural masonry", Heron, vol. 36 (1991), pp. 49-63.

(15) Dhanasekar, M.; Kleeman, P.; Page, A.W.: "Biaxial stress-strain relations for brick masonry", J. Struct. Eng., vol. 3(5) (1985), pp. 1085-1100. doi:10.1061/(ASCE)0733-9445(1985)111:5(1085)

(16) Page, A. W.: "The biaxial compressive strength of brick masonry", Proc. Inst. Civ. Eng., vol. 71(2) (1981), pp. 893-906. doi:10.1680/iicep.1981.1825 
(17) Lourenço, P. B.; Rots, J.: "On the use of micro-models for the analysis of masonry shear walls", Computer methods in structural masonry-2, Swansea (1993), pp 14-26.

(18) Salerno, G.; Bilotta, A.; Porco, F.: "A finite element with micro-scale effects for the linear analysis of masonry brickwork", Comput. Methods Appl. Mech. Eng., vol. 190 (2001), pp. 4365-4378. doi:10.1016/S0045-7825(01)00165-7

(19) Anthoine, A.: "Derivation of the in-plane elastic characteristics of masonry through homogenization theory", Int. J. Solids. Struct., vol. 32(2) (1995), pp. 137-163. doi:10.1016/0020-7683(94)00140-R

(20) Zucchini, A.; Lourenço P. B.: "A micro-mechanical model for the homogenization of masonry", Int. J. Solids Struct., vol. 39 (2002), pp. 3233-3255. doi:10.1016/S0020-7683(02)00230-5

(21) Massart, T. J.; Peerlings, R. H. J.; Geers, M. G. D.; Gottcheiner, S.: "Mesoscopic modeling of failure in brick masonry accounting for three-dimensional effects", Eng.Fract. Mech., vol. 72 (2005), pp. 1238-1253. doi:10.1016/j.engfracmech.2004.09.007

(22) Pietruszczak, S.; Ushaksaraei, R.: "Description of inelastic behavior of structural masonry", Int. J. Solids. Struct., vol. 40 (2003), pp. 4003-4019. doi:10.1016/S0020-7683(03)00174-4

(23) Gálvez, J. C.; Cervenka, J.; Saouma, V.; Cendón, D. A.: "A discrete crack approach to normal/shear cracking of concrete", Cement. Concr. Res., vol. 32 (2002), pp. 1567-1585. doi:10.1016/S0008-8846(02)00825-6

(24) Gálvez, J. C.; Cendón, D. A.; Planas, J.: "Influence of shear parameters on mixed-mode fracture of concrete", Int. J. Fract., vol. 118 (2002), pp. 163-189. doi:10.1023/A:1022883132117

(25) Hillerborg, A.; Modeer, M.; Petersson, P.: "Analysis of crack formation and crack growth in concrete by means of fracture mechanics and finite elements", Cement. Concr. Res., vol. 6 (1976), pp. 773-782. doi:10.1016/0008-8846(76)90007-7

(26) Sancho, J. M.; Planas, J.; Gálvez, J. C.; Reyes, E.; Cendón, D. A.: "An embedded cohesive crack model for finite element analysis of mixed mode fracture of concrete", Fatigue Fract. Engng. Mater. Struct., vol. 29 (2006), pp. 1056-1065. doi:10.1111/j.14602695.2006.01076.x

(27) Gálvez, J. C.; Elices, M.; Guinea, G. V.; Planas, J.: "Crack trajectories under mixed mode and non-proportional loading", Int. J. Fract., vol. 81 (1996), pp. 171-193. doi:10.1007/BF00033181

(28) Gálvez, J. C.; Elices, M.; Guinea, G. V.; Planas, J.: "Mixed mode fracture under proportional and non proportional loading", Int. J. Fract., vol. 94 (1998), pp. 267-284. doi:10.1023/A:1007578814070

(29) Wawryzynek, P.; Ingraffea, A.: FRANC2D: a two-dimensional crack propagation simulator, version 2.7. (1994).

(30) Carol, I.; Prat, P.; López, C. M.: "Normal/shear cracking model: application to discrete crack analysis", J. Eng. Mech., vol. 123 (1997), pp. 765-773. doi:10.1061/(ASCE)0733-9399(1997)123:8(765)

(31) RILEM 50-FMC Committee Fracture Mechanics of Concrete: "Determination of the fracture energy of mortar and concrete by means of three-point bend tests on notched beams", Mater. Construcc., vol. 18 (1986), pp. 285-290. 